\title{
IV. Additional remarks on the artificial production of cold
}

\section{Richard Walker Esq.}

To cite this article: Richard Walker Esq. (1828) IV. Additional remarks on the artificial production of cold , Philosophical Magazine Series 2, 4:19, 11-12, DOI: 10.1080/14786442808674703

To link to this article: http://dx.doi.org/10.1080/14786442808674703

里 Published online: 10 Jul 2009.

Submit your article to this journal $₫$

Џ Article views: 6

Q View related articles $\sqsubset$ 
sents with so much accuracy distances on the meridian, is no less exact when applied to measurements perpendicular to the meridian. At least this is the case in England in the instance we have examined; and a little time will show whether the same conclusion is confirmed or contradicted by the geodetical operations now executing on the continent.

June 13, 1828.

J. IVory.

IV. Additional Remarks on the Artificial Production of Cold. By Richard Walker, Esq., of Oxford.

To the Editors of the Philosophical Magazine and Annals. Gentlemen,

PERCEIVING an erratum in my communication inserted in the Philosophical Magazine for the present month, which renders my meaning rather obscure, I request you will have the goodness, in your next, to correct it thus:-at page 404, 8th line from the bottom, for "freely" - read "freshly."

I shall avail myself of this opportunity to present, in a cursory way, a few additional observations.

The drier and finer the mixed powder of sal ammoniac and nitre is, the better; and the pulverization is best effected, in the first instance, with a heated pestle. Glauber's salt in an efflorescent state, or which by long keeping or from access of air has changed to a powder, is unfit for the purpose; in this state producing heat by solution in water. The best way of preparing the frigorific mixture is by previously placing the powdered Glauber's salt, and giving il a level surface, at the bottom of the vessel, and upon that the mixed powder of sal ammoniac and nitre; adding first about half the quantity of water, and immediately after the remaining portion, stirring the whole together each time. The vessel containing the powdered salts, as above stated, may remain thus any convenient time before adding the water. [Care must be taken to stir the evaporating mixture towards the end of the process, and not to urge it too far.] Nitre being a much cheaper article than sal ammoniac, more easily reduced to powder, and producing about 16 degrees of cold by solution in water, may supersede the use of the mixed powder for cooling the water in which wine is placed. This powder, moreover, is useful, occasionally, as an addition to mixtures of ice and salt, to increase the power and accelerate the process.

The proportions of the articles given in my former paper are adapted to the temperature of $50^{\circ}$; at a higher tempera- 
ture, of course, the water will dissolve a somewhat larger portion of the salts, and the effect will be proportionably greater. Thus the most powerful mixture, given in my table of frigorific mixtures, consisting of phosphate of soda, nitrate of ammonia, and diluted nitric acid, will, when mixed at the temperature of $50^{\circ}$, produce a cold of $21^{\circ}$ below 0 ; and if mixed in due proportions at $100^{\circ}$, it will produce, in an instant, a cold of $20^{\circ}$; viz. a reduction of eighty degrees. By means of this mixture, as $I$ have been informed, water has been frozen solid " under" the line." I am, Gentlemen, Your most obedient servant,

Oxford, June 10, 1828.

Richard WaLker.

\section{Observations on the Geology of the Hyderabad Country*.}

THE country around Hyderabad is composed entirely of 1 granite, intersected by quartz, which generally runs north and south; and by trap, which has no definite direction.

The hills are generally in ridges. In some instances they are insulated, of a mamillary form, or abrupt and precipitous. The ridges are covered with detached masses of rock, and frequently (when seen at a little distance) have more the appearance of heaps of loose stones than of solid hills. The mamillary hills are almost always devoid of vegetation, having a smooth surface, with large detached lamellæ lying loosely on their sides, and apparently ready to slide or tumble down on the slightest impulse into the neighbouring valleys.

The insulated hills often present on one or more sides a smooth, perpendicular surface, which makes a very sudden curve at the top, or undulates, and thus contracts the summit of the hill.

Sometimes we find the surface of the granite forming part of an immense curve, and rising very gently and to a small height above the surrounding plain. In other instances it is waved, and presents a great variety of outline.

Huge blocks of granite are every where strewed over the country, and are often piled over each other in the valleys, or on the sides or summits of the hills, giving rise to the most fantastic shapes, and often closely resembling ruined buildings. It is not uncommon to see three or four immense masses of granite placed above ench other, with their surfaces nicely adapted, having somewhat the appearance of the ruin of an

* From the'Transactions of the Literary Society of Madras. Part i. page 79. 